\title{
FCRL2 Gene
}

National Cancer Institute

\section{Source}

National Cancer Institute. FCRL2 Gene. NCI Thesaurus. Code C117132.

This gene may play a role in B-cell development. 